\title{
Frecuencia del gen spvB en cepas de Salmonella spp. aisladas de niños con y sin diarrea.
}

\section{Artículo Original}

Fanny G. Concha-Valdez, Javier J. Flores-Abuxapqui, Miguel A. Puc-Franco, Mario R. Heredia-Navarrete.

Laboratorio de Microbiología, Centro de Investigaciones Regionales “Dr. Hideyo Noguchi”, Universidad Autónoma de Yucatán, Mérida, Yucatán, México.

\section{RESUMEN.}

Introducción. Algunos serotipos de Salmonella contienen plásmidos asociados a la virulencia (spv). La presencia de estos plásmidos aumenta la virulencia en ratones infectados experimentalmente, aunque en humanos aún no se ha establecido su papel durante la infección. La mayoría de los estudios realizados hasta la fecha se ha hecho en modelos experimentales, en los cuales las cepas de Salmonella producen septicemia en ratones, pero falla en producir grastroenteritis. Además, son muy pocos los trabajos donde se ha investigado si la presencia de estos plásmidos y/o de los genes codificados en los mismos guardan relación con la presencia de diarrea en humanos. El objetivo del trabajo fue determinar la frecuencia del gen $s p v B$ en cepas de Salmonella spp. aisladas de niños y establecer la relación que guarda con la presencia de diarrea en éstos.

Materiales y Métodos. Se estudiaron 170 cepas de Salmonella aisladas de niños con diarrea (50) y sin diarrea (120). A todas se les aplicó la técnica de
PCR, para amplificar un fragmento de $200 \mathrm{pb}$ que correspondía a la parte central del gen $s p v B$.

Resultados. De las 50 cepas de niños con diarrea, 16 fueron positivas a la presencia del gen $s p v B$ y 34 negativas. De 120 cepas aisladas de los niños sin diarrea, en 20 se amplificó el gen y en 100 no. De esta forma $36(21.18 \%)$ cepas fueron positivas a la presencia del gen $s p v B$, mientras que $134(78.82 \%)$ fueron negativas $\left(\mathrm{X}^{2}=4.09509, \mathrm{p}=0.0430\right)$.

Conclusión. Existe una asociación entre la presencia del gen $s p v B$ y la presencia de diarrea en los niños.

(Rev Biomed 2004; 15:201-206)

Palabras clave: Salmonella, Plásmido de virulencia, $s p v B$, PCR.

\section{SUMMARY.}

Frequency of the $s p v B$ gene in strains of Salmonella spp. isolated from children with and without diarrhea.

Introduction. Plasmids contribute importantly to

Solicitud de sobretiros: Fanny G. Concha-Valdez, Centro de Investigaciones Regionales "Dr. Hideyo Noguchi”, Universidad Autónoma de Yucatán, Av. Itzáes \# 490 x 59, Col. Centro. C.P. 97000, Mérida, Yucatán, México.

Tel. (52)(999) 92457 55, Fax (52)(999) 92361 20, E-mail: cvaldez@tunku.uady.mx

Recibido el 26/Julio/2004. Aceptado para publicación el 8/Noviembre/2004.

Este artículo está disponible en http://www.uady.mx/sitios/biomedic/revbiomed/pdf/rb041541.pdf

Vol.15/No.4/Octubre-Diciembre, 2004 
FG Concha-Valdez, JJ Flores-Abuxapqui, MA Puc-Franco, MR Heredia-Navarrete.

Salmonella virulence. Many Salmonella serotypes contain virulence plasmids (spv) that enhance their capacity for systemic infection in experimental animals (mice, cattle) after oral inoculation. The role of the virulence plasmid on the pathogenesis of salmonellosis or septicemia has been mainly studied in the murine model, while few studies have tried to establish the relationship between virulence plasmids and the presence of diarrhea in humans.

Materials y Methods. We studied 50 strains of Salmonella spp. isolated from children with diarrhea and 120 without diarrhea. We used the PCR method to amplify a $200 \mathrm{bp}$ fragment of the $s p v B$ gene in order to investigate its presence in the samples.

Results. From the 50 strains isolated from children with diarrhea, in $16(32 \%)$ the $s p v B$ gene was amplified, and 34 (68\%) were negative. From the 120 strains isolated from children without diarrhea, in 20 $(17 \%)$ the $s p v B$ gene was amplified and $100(83 \%)$ were negative. A value of 4.09 for $\mathrm{c}^{2}$ was determined $(\mathrm{p}=0.043)$. Thus, from 170 strains studied, $36(21 \%)$ were positive to the presence of the $s p v B$ gene, and 134 (79\%) were negative.

Conclusions. We observed a significant association between the $s p v B$ gene presence and diarrhea in children. (Rev Biomed 2004; 15:201-206)

Key words: Salmonella, virulence plasmid, $s p v B$, PCR.

\section{INTRODUCCIÓN.}

Las enfermedades diarreicas están entre las principales causas de morbilidad y mortalidad infantil en los países en desarrollo, donde los niños pueden padecer hasta ocho o más episodios de diarrea durante los primeros 12 meses de vida $(1,2)$. La diarrea infantil en los países en desarrollo se asocia con patógenos bacterianos en la mayoría de los casos, y esta predominancia está asociada a una higiene deficiente, particularmente en lo que respecta a la disposición de las heces de humanos y de animales, y a la preparación de alimentos (3).

Las salmonelas son microorganismos complejos que poseen varios factores de virulencia, entre los que se encuentran los antígenos de superficie, la invasividad, la producción de toxinas (enterotoxina y citotoxina) y la presencia de plásmidos que confieren virulencia $(4,5)$.

Los plásmidos de virulencia varían en tamaño, dependiendo del serotipo: $95 \mathrm{kbp}$ para Salmonella typhimurium; $60 \mathrm{kbp}$ para $S$. enterica; $80 \mathrm{~Kb}$ para S. dublin y de 50 a $110 \mathrm{kbp}$ para $S$. choleraesuis. Aunque difieren en tamaño, todos tienen una región altamente conservada de $8 \mathrm{kbp}$ involucrada con la virulencia (6). Esta región de $8 \mathrm{kbp}$ contiene un grupo de cuatro genes estructurales, $s p v A, s p v B, s p v C$, $\operatorname{spv} D$ y un gen regulador $s p v R$, que son transcritos como un operón y son regulados "in vitro" durante la fase estacionaria de crecimiento y por el medio ambiente intracelular (7). Además, se ha demostrado que incrementa la tasa de crecimiento de la bacteria dentro de las células huésped en las primeras semanas de la infección sistémica en ratones $(8,9,10)$.

Análisis mutacionales de la región $s p v$ de $S$. $d u b l i n$, indican que $s p v R$ y $\operatorname{spv} B$ son genes esenciales para la virulencia en ratones y que $s p v C$ y $s p v D$ juegan un papel accesorio. En S. typhimurium se ha demostrado que la mutación en los genes $s p v C$ y spv $D$ tienen efectos significativos sobre la virulencia de esta serovariedad $(7,11,12)$.

En un estudio hecho por Matsui y col., lograron determinar que los genes $s p v B$ y $s p v C$ pueden remplazar la virulencia del plásmido completo en el serotipo thyphimurium después de ser inoculados subcutáneamente en ratones (13). La proteína SpvB es una ADP ribosiltransferasa y parece ser la principal responsable de la virulencia del locus $s p v$, ya que se ha visto que enzimas $\mathrm{ADP}$ ribosiltransferasas (toxinas de cólera, difteria, etc.,) son los factores de virulencia clave para una gran variedad de bacterias patógenas extracelulares $(14,15)$. Lesnick y col., sugirieron que una de las funciones de la proteína $S p v B$ es la de una toxina ADP-ribosilante intracelular, esencial para la patogénesis de infecciones por Salmonella (15).

La mayoría de los estudios realizados para establecer la importancia del plásmido de virulencia en cepas de Salmonella se ha hecho relacionándolo con infecciones de tipo sistémico en animales y en el

\section{Revista Biomédica}




\section{Frecuencia del gen $\mathrm{spvB}$ en cepas de Salmonella spp.}

hombre $(8,16,19,20)$.

Por todo lo anterior sólo se consideró estudiar la prevalencia del gen $s p v B$ en cepas de Salmonella spp., y establecer si juega un papel con la presencia de diarrea, ya que hasta ahora este hecho sólo se ha corroborado en modelos animales $(8,10,17,18)$ y hay pocos estudios realizados en humanos $(19,20)$.

\section{MATERIAL Y MÉTODOS.}

Cepas de Salmonella. Se estudiaron 170 cepas de Salmonella spp. aisladas de niños con y sin diarrea (50 y 120 respectivamente) en un estudio previo. También se utilizaron cepas control; una positiva que presentaba el plásmido de virulencia $(s p v+)$ y una negativa ( $s p v-)$, sin él.

Todas las cepas fueron tipificadas en el Instituto de Diagnóstico y Referencia Epidemiológicos "Dr. Manuel Martínez Báez", SSA.

Preparación de ADN plasmídico. Se purificó el ADN plasmídico de cada una de las 170 cepas de acuerdo a Engebrecht y col.(21), con un método que consiste en lisis alcalina y precipitación con etanol. PCR. La reacción en cadena de la polimerasa se le aplicó a los ADNs de todas las cepas de acuerdo con Kramer y Coen (22). Los iniciadores y las cepas controles fueron proporcionados por el Dr. Paul Gulig, del Departamento de Genética y Microbiología Molecular, Colegio de Medicina de la Universidad de Florida, en Gainesville, Fl., EU. La utilización de éstos permite identificar un fragmento de $200 \mathrm{pb}$ del gen $s p v \mathrm{~B}$ del plásmido de virulencia de Salmonella. En todas las reacciones se utilizaron los controles positivo (ADN de la cepa $s p v+$ ) y negativo (ADN de la cepa $s p v$-).

\section{Cuadro 1.}

Frecuencia del gen $s p v B$ en cepas de Salmonella spp. aisladas de niños con y sin diarrea.

\begin{tabular}{lllllll}
\hline & Cepas & \multicolumn{2}{l}{ spvB +} & \multicolumn{2}{l}{ spvB- } & Total \\
\hline Casos & Diarrea & $\mathbf{1 6}$ & $\mathbf{3 2 \%}$ & $\mathbf{3 4}$ & $\mathbf{6 8 \%}$ & $\mathbf{5 0}$ \\
Control & No diarrea & $\mathbf{2 0}$ & $\mathbf{1 7 \%}$ & $\mathbf{1 0 0}$ & $\mathbf{8 3 \%}$ & $\mathbf{1 2 0}$ \\
Total & & 36 & & 134 & & 170 \\
\hline
\end{tabular}

Todos los productos de amplificación fueron sometidos a electroforesis en geles de agarosa al $1 \%$ teñidos con bromuro de etidio. Los resultados se obtuvieron mediante la observación del gel en un transluminador de luz ultravioleta (figura 1).

Métodos estadísticos. Se utilizó la prueba de $\mathrm{X}^{2}$ del programa estadístico Epi-stat. Se obtuvo la frecuencia del gen $s p v B$ en la cepas de salmonela.

\section{RESULTADOS.}

Se encontraron cerca de 30 serotipos diferentes, entre los que destacan: S. agona, typhimurium, infantis, anatum, poona, enteritidis, ohio, cerro, etc.

Se determinó que la presencia del gen $s p v B$ está typhimurium.

Se aplicó la técnica de PCR a un total de 170 cepas de Salmonella spp. y los resultados están condensados en el cuadro 1.

De las 170 cepas estudiadas, 50 eran de niños con diarrea y 120 de niños sin diarrea. De las primeras, 16 fueron positivas a la presencia del gen $s p v B$, y 34 negativas. De las cepas aisladas de los niños sin diarrea, en 20 se observó el gen y en 100 no. De las 170 cepas, 36 (21.18\%) fueron positivas a la presencia del gen $\operatorname{spv} B$, mientras que 134 (78.82\%) fueron negativas.

Después de aplicar el estadístico de $X^{2}=$ 4.09509 y $\mathrm{p}=0.0430$, se determinó que existe una relación estadísticamente significativa entre la presencia del gen $s p v B$ y la presencia de diarrea en los niños. más relacionada con los serotipos enteritidis y

$$
X^{2}=4.09509 \quad p=0.04300
$$


FG Concha-Valdez, JJ Flores-Abuxapqui, MA Puc-Franco, MR Heredia-Navarrete.

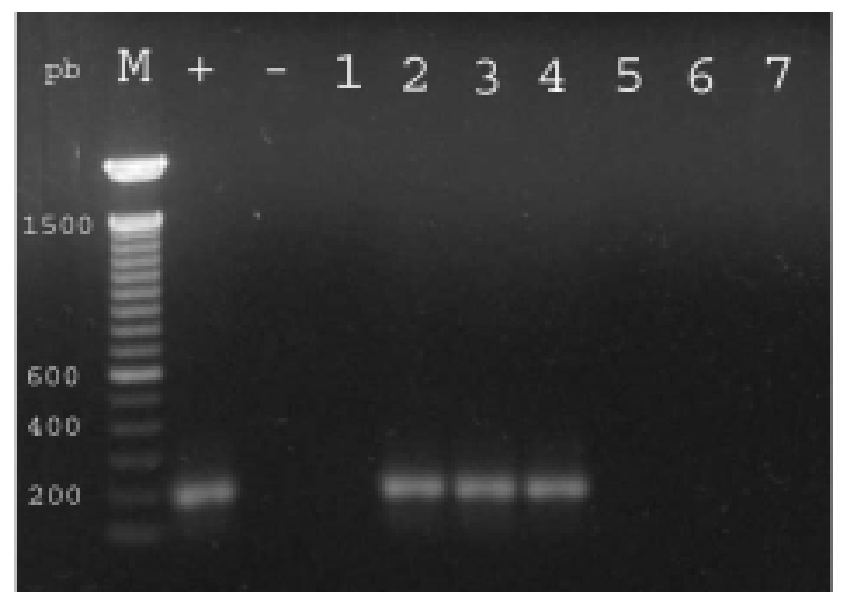

Figura 1.- Detección del gen $s p v \mathrm{~B}$ en cepas de Salmonella spp por PCR. Se muestran los fragmentos correspondientes al amplicón de aproximadamente 200 pares de bases (pb). (M), marcador de peso molecular; los carriles marcados $(+)$ y (-) corresponden a las cepas control de Salmonella $s p v B^{+}$y $s p v B^{-}$respectivamente. Se observa que en al menos 3 de los carriles la presencia del gen $s p v B$ de Salmonella.

\section{DISCUSIÓN.}

Salmonella es un microorganismo ampliamente estudiado por el cuadro patogénico que desarrolla en el huésped, pero aún existen interrogantes acerca del mecanismo de acción de los factores de virulencia expresados durante la infección. Uno de éstos es la expresión de los genes en los plásmidos asociados a la virulencia, denominados $s p v$. Se sabe que existe una fuerte relación entre la presencia de estos plásmidos y la septicemia $(5,10,15)$, pero no existen suficientes estudios encaminados a explicar la relación que guardan la presencia de estos genes y/o plásmidos con la presencia del cuadro diarreico en humanos $(18,19)$. Casi todos utilizan el modelo murino y cepas de $S$. typhimurium $(8,13)$, en las cuales sí se ha demostrado que hay relación entre la presencia de estos plásmidos y el incremento en la virulencia de las cepas.

Por todo esto, en este trabajo se pretendía demostrar cuál es la relación entre estos plásmidos y la presencia de diarrea en niños.

En un trabajo realizado por Matsui y col. (13) se demostró que la sola presencia de los genes $s p v B$ y $s p v C$ era suficiente para conferir la virulencia del plásmido completo en el serotipo typhimurium, por lo cual sólo buscamos al gen $s p v B$ para demostrar la relación entre la presencia del plásmido de virulencia y el cuadro diarreico.

Fierer y col. (1992) estudiaron la presencia de plásmidos de virulencia en cepas de salmonela aisladas de heces fecales y de sangre, y obtuvieron $42 \%$ y $76 \%$ respectivamente de cepas positivas a la presencia de los plásmidos (18). Aunque la frecuencia observada en nuestro estudio es menor $(21.17 \%)$, hay que tomar en cuenta que el número de cepas aisladas de heces por Fierer y col. fue de 79 contra 170 estudiadas por nosotros. Otro detalle importante es que ellos únicamente trabajaron con el serotipo typhimurium, en el cual se sabe que la virulencia está fuertemente relacionada con la presencia del plásmido.

Estudios realizados por Wallis y col. y Tsolis y col., encaminados a relacionar la presencia de gastroenteritis con la presencia de los genes $s p v$, fueron hechos en ganado vacuno como modelo experimental. Estos grupos llegan a la conclusión de que los genes $s p v$ son requeridos para la virulencia completa así como para la persistencia en sitios sistémicos, pero no son indispensables para la patogénesis de la gastroenteritis bovina $(16,17)$. Además, los serotipos estudiados por ellos fueron dublin y typhimurium, muy relacionados con la gastroenteritis en bovinos, en tanto que nosotros utilizamos cerca de 30 serotipos diferentes entre los que se encuentran: S. agona, typhimurium, infantis, enteritidis, anatum, poona, ohio, cerro, etc. que son los más frecuentes en la entidad, encontrándose que la presencia del gen $s p v B$ está más relacionada a los serotipos enteritidis y typhimurium.

Por último, otro hecho que es importante resaltar es que existe un número elevado de cepas aisladas de niños sin diarrea que presentan el plásmido, lo que nos indica que posiblemente se hallen involucrados otros mecanismos de virulencia, además de la presencia del plásmido para producir la enfermedad.

\section{Revista Biomédica}




\section{Frecuencia del gen $\mathrm{spvB}$ en cepas de Salmonella spp.}

\section{AGRADECIMIENTOS.}

Este trabajo de investigación se llevó a cabo con financiamiento del Consejo Nacional de Ciencia y Tecnología, con el convenio 498100-5-L0007M, instancia a la cual hacemos expreso nuestro agradecimiento.

\section{REFERENCIAS.}

1.- Sepúlveda AJ. Epidemiología de la enfermedad diarreica aguda en México. Secretaría de Salud, México. OPS. UNICEF. 1991.

2.- Suárez G, Flores JJ, Puc MA, Heredia MR. Excreción de Salmonella en las heces durante los primeros meses de vida. Rev Lat Amer Microbiol 1991;33:245-7.

3.- Miller SI, Alpuche AC. Infección por Salmonella. En: Torregosa L, Santos JI, Rodríguez RS, Velásquez L, García LA, Alpuche CM, editores. Enfermedades diarreicas en el niño. 10a ed. México: Interamericana Mc Graw Hill; 1996. p.140-51.

4.- Goosney DL, Knoechelmand D, Finlay B. Enteropathogenic Escherichia coli, Salmonella and Shigella: Masters of host cell citoskeletal explotation. Emerg Infect Dis 1999; 5:216-20.

5.- Fierer J, Eckmann L, Fang f, Pfeifer C, Finlay BB, Guiney D. Expression of the Salmonella virulence plasmid gene $s p v B$ in cultured macrophagos and nonphagocytic cells. Infect Immun 1993; 61:5231-5.

6.- Marcus SL, Brumella JH, Pfeifer CG, Finlay BB. Salmonella pathogenicity islands: big virulence in small packages. Microb Infect 2000; 2:145-56.

7.- El-Gedaily A, Paesold G, Krause M. Expression profile and subcellular location of the plasmid-encoded virulence (Spv) proteins in wild-type Salmonella dublin. Infect Immun 1997; 65:3406-11.

8.- Gulig P, Doyle TJ, Hughes JA, Matsui H. Analysis of host cells associated with the Spv-mediated increased intracellular growth rate of Salmonella typhimurium in mice. Infect Immun 1998; 66:2471-85.

9.- Kowarz L, Coynault C, Veronique RS, Norel F. The Salmonella typhimurium katF (rpoS) gene: Cloning nucleotide sequence, and regulation of spvR and spvABCD virulence plasmid genes. J Bacteriol 1994; 176:6852-60.

10.- Libby SJ, Adams LG, Fitch TA, Allen C, Witford HA, Buchmeier NA, et al. The spv genes on the Salmonella dublin virulence plasmid are required for severe enteritis and systemic infection in natural host. Infect Immun 1997; 65:1786-92.

11.- Chen CY, Buchmeier NA, Libby S., Fan FC, Krause M, Guiney DG. Central regulatory role for the RpoS sigma factor in expression of Salmonella dublin plasmid virulence genes. J Bacteriol 1995; 177:5303-9.

12.- Grob P, Kahn D, Guiney D. Mutational characterization of promoter regions recognized by the Salmonella dublin virulence plasmid regulatory protein SpvR. J Bacteriol 1997; 179:5398-406.

13.- Matsui H, Bacon CM, Garlinton WA, Doyle TJ, Roberts S, Gulig PA. Virulence plasmid-borne $s p v B$ and $s p v C$ can replace the 90-kilobase plasmid in conferring virulence to Salmonella enterica serovar typhimurium in subcutaneously inoculated mice. J Bacteriol 2001; 183:4652-8.

14.- Taira S, Baumann M, Rijkonen P, Sukupolvi S, Rhen M. Amino-terminal sequence analysis of four plasmidencoded virulence-associated proteins of Salmonella typhimurium. FEMS Microbiol Lett 1991; 61:319-23.

15.- Lesnick ML, Reiner NE, Fierer J, Guiney DG. The Salmonella $\operatorname{sp} v B$ virulence gene encodes an enzyme that ADP-ribosylates actin and destabilizes the cytoskeleton of eukaryotic cells. Mol Microbiol 2001; 39:1464-70.

16.- Gulig PA, Doyle TJ, Clare-Salzer MJ, Maiese RL, Matsui H. Systemic infection of mice by wild-type but, not Spv-Salmonella typhimurium enhanced by neutralization of gamma interferon and tumor necrosis factor alpha. Infect Immun 1997; 65:9191-7.

17.- Wallis TS, Paulin SM, Plested JS, Watson PR, Jones PW. The Salmonella dublin virulence plasmid mediates systemic but not enteric phases of salmonellosis in cattle. Infect Immun 1995; 63: 2755-61.

18.- Tsolis RM, Adams LG, Ficht TA, Bäumler AJ. Contribution of Salmonella typhimurium virulence factors to diarrheal disease in calves. Infect Immun 1999; 67: 487985.

19.- Fierer J, Krause M, Tauxe R, Guiney D. Salmonella typhimurium bacteremia: Association with the virulence plasmid. Infect Dis 1992; 166:639-42.

20.- Montenegro MA, Morelli G, Helmuth R. Heteroduplex analysis of Salmonella virulence plasmids and their

Vol.15/No.4/Octubre-Diciembre, 2004 
FG Concha-Valdez, JJ Flores-Abuxapqui, MA Puc-Franco, MR Heredia-Navarrete.

prevalence in isolates of defined sources. Microb Pathog 1991; 11:391-7.

21.- Engebrecht J. Brent R, Kaderbhai MA. Minipreps of plasmid DNA. En: Ausbel F, Brent R, Kingston RE, Moore DD, Seidman JG, Smith JA, Struhl K, editores. Short protocols in Molecular Biology. 3a. ed. USA: John Wiley and Sons, Inc.; 1995. p.16-8.

22.- Kramer MF, Coen DM. Enzymatic amplification of DNA by PCR: Standard procedure and optimization. En: Ausbel F, Brent R, Kingston RE, Moore DD, Seidman JG, Smith JA, Struhl K, editors. Short protocols in Molecular Biology. 3er. ed. USA: John Wiley and Sons, Inc.; 1995. p.3-5. 